\title{
RELATIVE STERILITY OF THE HANDS OF CERTAIN METAL WORKERS *
}

\author{
BY \\ IWO LOMINSKI and G. RUSSELL THOMSON
}

\author{
From the Departments of Bacteriology and Surgery, Glasgow University and the Western Infirmary, Glasgow
}

In the course of an investigation of the flora of wounds the striking observation was made that the skin of the hands of certain workmen was remarkably free from bacteria. It appeared that the individuals in question were metal workers who handled metal filings $\dagger$ and engine oil. Metal workers who handled filings but not oil, those who handled oil and metal but not in the form of filings, similarly those who handled oil alone-did not present the phenomenon. Where a worker handling oily metal filings worked with his sleeves rolled up, the skin of the forearms showed the same relative lack of bacterial flora. It was found that this relative sterility of the hands was not peculiar to individuals, since control observations established that other parts of their body (neck, abdomen, thigh and arms) were just as heavily infected as corresponding parts of other people. Thus, only the parts exposed to contact with both metal filings and oil were sterile.

The phenomenon was verified on larger numbers. The investigation was carried out as follows: workmen from many different works were examined; the tests were carried out in batches and blindly, i.e. without the bacteriologist knowing the occupation of the individual whose skin was examined. Each batch of ten persons included two controls of another occupational class. For each individual a special dossier was drawn up containing details of previous history, hygienic conditions in general, frequency of bathing, hand-washing, and the duration of the present occupation; the fact whether the worker was in contact with metal filings (type of metal) and engine oil (whether hot) was ascertained with particular care by evidence of the worker and the manager; if any doubts arose the individual was observed at work by one of the authors. All were excluded from consideration in whom there were factors which might affect the bacteriological result, such as the use of special methods of bleaching and cleansing the skin by lotions containing detergents or hypochlorites, or the use of antiseptic soaps. Workmen in contact with tar and paints were also excluded.

* Work done with the support of the Scottish War Wounds Committee of the Medical Research Council.

$\dagger$ The metal filings were derived from shells, ships' plates, brass and steel plates and various alloys containing copper, manganese, etc., which cannot be specified more particularly.
The technique followed for the estimation of the bacterial flora was a modification of that originally used by De Waal in Edinburgh (personal communication). The load of infection was estimated by taking consecutively two swabs (soaked in sterile saline) from each skin area. From each individual six swabs were taken-two each from the palm, the back of the hand, and the outer side of the forearm. Samples were always taken from similar areas of an inch square of the right extremity; the interval between the last hand-wash and the taking of the swabs was at least two hours. Each swab was plated on two blood-agar Petri dishes. (No search for anaerobes was made.) The approximate number of colonies obtained by averaging the growth on the four Petri dishes was expressed in grades according to the following scale:

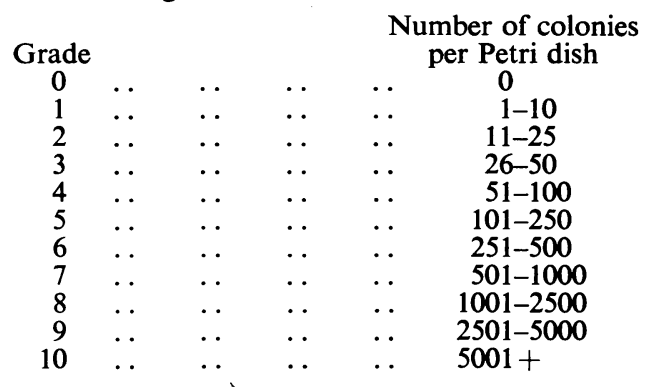

Almost 50 per cent. of all individuals were examined twice at a fortnight's interval-the difference between the two was negligible; the results quoted for such individuals are the average of the two examinations.

A series of 40 oily metal-filings workers was compared with a control population of 86 individuals comprising various occupations -22 carpenters, 18 clerks, 17 medical personnel (10 doctors, 7 nurses), 12 metal workers not in contact with both metal filings and oil, 9 porters and labourers and 8 housewives.* Differences of social class were purposely not avoided, since it was thought that better financial conditions might favour personal hygiene and bacteriological cleanness; thus a con-

* Many more workers of both groups have been examined though the results obtained with them were similar to those given below, they were excluded from statistical analysis because detailed information regarding their personal hygiene could not be ascer- 
trol population consisting of many social classes including medical personnel, puts the odds against the population of oily metal-filings workers, and so makes the finding of relative sterility of the latter more significant, particularly as with few exceptions the oily metal-filings workers had only one bath a week and one hand-wash a day after their work. The group of oily metal-filings workers contained only males, and of the control about one-eighth (11) were females; thus difference of sex was practically excluded.

The palm of the hand rather than the back was chosen as a criterion for analysis for the following reasons-it was found that the back of the hand is subject to greater individual variations in the load of bacteria than the palm; in several instances among the control population the back of the hand was found relatively 'clean,' but only once was an ' almost sterile' palm encountered; this was in the case of a surgeon shortly after washing the hands. (A few hours later the hand was found again to be heavily infected.) It was also thought that the back of the hand was less in contact both with sources of infection and possible antiseptic agencies (metal filings and oil).

\section{Results}

Table 1 shows the frequency distribution of individuals in (a) the population of oily metal-filings workers and (b) the control population according to grades of bacterial infection of the skin of the palm.

It appears from the table that (a) the population of oily metal-filings workers is strikingly bacteriumfree; 30 per cent. of it falls into grade $0 ; 87.5$ per cent. into grades $0-2$, and 92.5 per cent. into grades $0-3$. (b) The control population is much more heavily infected; none of it falls into grade 0 , the bulk of it-59.2 per cent.-into grades $4-6$, the rest is spread over all other grades. Comparison of the carpenters with the rest of the control population, using a fourfold table, yields a value of $P$ between 0.02 and 0.01 , so that there is probably a significant difference. However, the carpenters were not excluded from the controls, in order that the test of significance of the difference between oily metal-filings workers and others might be as stringent as possible. The group of 17 individuals belonging to the medical personnel is entirely similar to the rest of the control population. Thus the oily metal-filings workers are in a class by themselves.

The difference of bacterial load of the population of oily metal-filings workers and the control population has been tested by calculating the $\chi^{2}$ of such distribution (Table 2 ) and by calculating the relation

TABLE 2

FOURFOLD TABLE SHOWING INCIDENCE OF CLEAN AND DIRTY INDIVIDUALS IN THE TWO CATEGORIES OF OILY METALFILINGS WORKERS AND CONTROL OCCUPATIONS (TAKING GRADE 2 AS LIMIT OF CLEANNESS)

\begin{tabular}{c|c|c|c}
\hline & $\begin{array}{c}\text { Oily metal- } \\
\text { filings } \\
\text { workers }\end{array}$ & $\begin{array}{c}\text { Various } \\
\text { other occu- } \\
\text { pations }\end{array}$ & Total \\
\hline $\begin{array}{c}\text { Clean } \\
\text { Grade 0, 1 and 2 .. } \\
\text { Dirty }\end{array}$ & 35 & 12 & 47 \\
Grade 3 and above & 5 & 74 & 79 \\
\hline Total .. .. & 40 & 86 & 126 \\
\hline$x^{2}=60.03$ & \multicolumn{2}{|c|}{$P=c a .10^{-12.231}$}
\end{tabular}

The $\chi^{2}$ was calculated according to Bradford Hill (1942). The value of $P$ was taken from the tables of Pearson (1924).

TABLE 1

\begin{tabular}{|c|c|c|c|c|c|c|c|}
\hline \multirow{3}{*}{ Grade } & \multirow{2}{*}{\multicolumn{2}{|c|}{ Oily metal-filings workers }} & \multicolumn{5}{|c|}{ Control population } \\
\hline & & & \multirow{2}{*}{$\frac{\text { Carpenters }}{\text { Number }}$} & \multirow{2}{*}{$\begin{array}{l}\text { Medicals } \\
\text { Number }\end{array}$} & \multirow{2}{*}{$\begin{array}{l}\text { Others } \\
\text { Number }\end{array}$} & \multicolumn{2}{|c|}{ Total control population } \\
\hline & Number & Per cent. & & & & Number & Per cent. \\
\hline $\begin{array}{r}0 \\
1 \\
2 \\
3 \\
4 \\
5 \\
6 \\
7 \\
8 \\
9 \\
10\end{array}$ & $\begin{array}{r}12 \\
16 \\
7 \\
2 \\
2 \\
1 \\
0 \\
0 \\
0 \\
0 \\
0\end{array}$ & $\begin{array}{r}30.0 \\
40.0 \\
17 \cdot 5 \\
5 \cdot 0 \\
5 \cdot 0 \\
2 \cdot 5 \\
0 \\
0 \\
0 \\
0 \\
0\end{array}$ & $\begin{array}{l}0 \\
4 \\
4 \\
3 \\
4 \\
0 \\
2 \\
3 \\
1 \\
1 \\
0\end{array}$ & $\begin{array}{l}0 \\
1 \\
1 \\
1 \\
7 \\
3 \\
2 \\
1 \\
0 \\
0 \\
1\end{array}$ & $\begin{array}{r}0 \\
0 \\
2 \\
2 \\
11 \\
13 \\
9 \\
2 \\
4 \\
1 \\
3\end{array}$ & $\begin{array}{r}0 \\
5 \\
7 \\
6 \\
22 \\
16 \\
13 \\
6 \\
5 \\
2 \\
4\end{array}$ & $\begin{array}{r}0 \\
5.8 \\
8.1 \\
7.0 \\
25.6 \\
18.6 \\
15.0 \\
7.0 \\
5.8 \\
2.4 \\
4.7\end{array}$ \\
\hline Total $\quad$. & 40 & - & 22 & 17 & 47 & 86 & - \\
\hline
\end{tabular}

The organisms isolated were in decreasing order of frequency, Staph. albus, haemolytic diphtheroids, various sarcinae, non-haemolytic diphtheroids, anthracoids, yeasts, mucors, penicillia, aspergilli, Staph aureus, Enterococcus, Pneumococcus, Str. haemolyticus, Str. viridans, non-haemolytic streptococci, Gram-positive air cocci and bacilli, coliforms, micrococci and Klebsiellas. 
of the difference of proportions of clean individuals in both populations, to the standard error of their difference, i.e. the significance of the difference (Table 3). For both calculations grade 2 has been taken as the limit of bacteriological cleanness.

TABLE 3

TABLE SHOWING THE PROPORTION OF CLEAN INDIVIDUALS IN THE TWO CATEGORIES OF OILY METAL-FILINGS WORKERS AND CONTROL OCCUPATIONS, TAKING GRADE 2 AS LIMIT OF CLEANNESS

Proportion of clean individuals in-

(a) Oily metal-filings workers $\quad .87 \cdot 5$ per cent.

(b) Control population

Percentage difference between the two

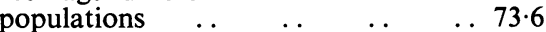

The standard error of this difference $\ldots 6.42$ per cent

The difference is 11.46 times its standard error.

\section{Discussion}

It appears from the present study that the skin of the palm of workers in contact with metal filings and oil carries a lower load of bacteria than that of other people, and statistical assessment indicates that the phenomenon is not likely to arise by chance. It may therefore be concluded that there is an association between contact with metal filings and the bacteriological cleanness of the skin, which is presumably causal.

The explanation of the relative sterility of skin exposed to metal filings and oil is not clear. One of the factors might be the diminished chances of bacterial contamination of oily metal filings workers. The findings, however, with medical personnel and metal workers not in contact with metal filings and oil, do not favour such an explanation; the hands of oily metal-filings workers are strikingly clean in the bacteriological sense irrespective of the hygienic conditions. Experiments in vitro suggest that the phenomenon is related to the oligodynamic action of fine metal particles-i.e. the antiseptic action produced by traces of such substances, owing to their being electively fixed by sensitive organisms and so accumulating in these. The relative sterility of the hands of carpenters is probably related to the antibacterial action of moulds, anthracoids, etc., acquired through handling wood and sawdust. Such organisms are present in those materials as well as on the hands and in vitro almost all the species were capable of inhibiting the common organisms of the human skin, such as Staph. albus and aureus, sarcinae, diphtheroids and enterococci.

In view of the influence which the bacterial flora of the skin exerts on the infection of wounds and so on the rate of healing, the relative sterility of those who handle oily metal filings is not merely of theoretical interest. The somewhat surprising information was elicited from those men that injuries to their hands usually healed without becoming septic; this was borne out by our experience. Since ' greasy' occupations frequently involve contact with metal in fine division the statement of Iselin (1940) that 'the hands of workmen and particularly those soiled with grease, appear to harbour only attenuated organisms' may refer to this class of cases.

We are indebted to Mr. W. Arthur, Department of Mathematics, the University, for scrutinizing the statistical analysis.

\section{REFERENCES}

Bradford Hill, A. (1942). Principles of Medical Statistics, London, 3rd ed., p. 93.

Iselin, M. (1940). Surgery of the Hand. London, p. 10.

Pearson, K. (1924). Tables for Statisticians and Biometricians. Cambridge, 2nd ed., p. 31 